\title{
PLAYING WITH BOUNDARIES: SELF AND DIALOGUE IN AN INDIAN-AMERICAN FATANA PERFORMANCE
}

\author{
Christine Garlough
}

\begin{abstract}
For many Indian-American immigrants, answering the question "Who are you?" requires significant negotiation. This inquiry, complicated by the diversity found on the Indian subcontinent, raises issues relating to nationalism and transnationalism and often results in play with identity boundaries. Consequently, in this article I argue for studying immigrants and their experiences through a dialogic framework, expanding upon a Bakhtinian (Bakhtin 1963, 1968, 1979 and 1986) conception of the self. I apply this framework to a particular Indian-American folk performance of Gujarati women's songs called fatanas. The negotiation between us and them, self and other apparent in this folk performance raises important issues surrounding the construction of permanent and temporary immigrant identities. Beyond this, I argue that while the voices of all people are irreducibly heterogeneous, immigrants, who belong to more than one community and participate in more than one cultural sphere, often are in a position characterized by an enhanced awareness of cultural diversity. Consequently, they acquire a heightened potential for self-reflection and reflexivity. This case study illustrates such potential, containing diverse representations of cultural and personal identity within a single immigrant performer, as well as a single Indian-American community.
\end{abstract}

Key words: Bahktinian conception of the self, fatana, folk performance, Gujarati women's songs, Indian-American folklore

In recent years, many folklore scholars have cited Appadurai's (1990) article, "Disjuncture and Difference in the Global Cultural Economy", in which he argues convincingly for the importance of attending to the interactive nature of the ethnoscapes in today's world. Around these ethnoscapes there are no rigid boundaries; rather, edges blur when cultural forms, grounded in distinct traditions, interact. This interaction often results in a recognition, that we are all traveling through the networks of a world bearing the tension between our particular inheritance and potentially common culturescapes; that we all, in some sense, live in border conditions (Chambers 1994: 14). This emphasis upon the movement and mediation of cultural boundaries is highlighted in the lives of immigrants and other transient groups of people. Immigrants, who belong 
to more than one community and participate in more than one cultural sphere, are in a position characterized by a heightened awareness of cultural diversity and ambiguity (Kirshenblatt-Gimblett 1983: 43). Consequently, the borders of immigrant personal and community identity shift as they come into dialogue with discourse from other communities, cultures, histories, and selves. This dialogic interaction, rather than leading to closure, allows for the strategic negotiation of group and individual identity in the immigrant community.

Working from this theoretical base, this paper endeavors to illustrate how a Bakhtinian conception of dialogic culture and dialogic self (1968, 1979 and 1984) can be applied to the study of immigrant folk performances. Specifically, I utilize Bakhtin's notion of the dialogic in an 'ethnography of the particular' which focuses on a marriage sangeet - an evening of music and dance imagined and constructed by a diasporic community of Indian-Americans in Madison, Wisconsin. This particular sangeet wove together a variety of different cultural genres and styles representing diverse regions and ethnic groups to celebrate the wedding of a first-generation Indian-American woman to a thirdgeneration Norwegian-American man. In combination, these individual performances created a dialogic narration that centered upon themes of kinship, self, gender, and diaspora.

This paper is concerned most specifically with the performance of a Gujarati folk song genre called fatana. Fatanas, ordinarily sung by women, are humorous insult songs that are tied thematically to issues surrounding kinship and marriage. This practice is multi-layered in the sense that it evokes laughter and provides pleasure, while challenging and deconstructing social order. A carnivalesque type of hegemonic humor, fatanas may be subversive or conservative. And, of course, not everyone appreciates the fun. My analysis of the fatana performed in this particular immigrant performance revolves around four main issues. First, the aspects of self highlighted in the presentations. Second, the elements gender and kinship embedded in the fatana performance. Third, the appropriation and transformation of this folk form by a young second-generation Indian-American male. Fourth, how the sharing of this humorous folk song genre helped to negotiate and, in some cases, establish social bonds.

Drawing most heavily upon the work of Tedlock (1991), Tedlock \& Mannheim (1995), and Hill (1995), my analysis attends to the continual production, reproduction, and revision of cultures. In stark contrast to more autonomous views of culture, the dialogic approach emphasizes culture as a process of emergent interaction. However, dialogical ethnography is not merely the celebration of a multiplicity of diverse voices. One of the key challenges is to reformulate the problem of the location of culture within a social ontology in which neither 
individuals nor collectivities are basic units (Tedlock \& Mannheim 1995: 8). With these issues in mind, I present my arguments and data through an interactive framework of performance texts, personal analysis, and individual portraits of the performers.

\section{BAKHTIN'S DIALOGIC}

Bakhtin's conception of the dialogic has been used and misused by an increasing number of scholars in recent years. Misuse has occurred largely as a result of some scholars' tendency to reduce the notion of dialogue to a turn-taking interaction between different speakers. However, Bakhtin's formulation of the dialogic encompasses substantially more. In Problems of Dostoevsky's Poetics, Bakhtin states

dialogic relationships are a much broader phenomenon than mere rejoinders in a dialogue laid out compositionally in a text; they are almost a universal phenomena, permeating all human speech and all relationships and manifestations of human life - in general everything that has meaning and significance (Bakhtin 1963: 40).

Not only are individual voices in dialogue, but so are histories, cultures, consciousness, truths, and texts. In essence, every piece of discourse is part of an open-ended dialogue. All discourse is entangled, shot through with shared thoughts, points of view, alien value judgments and accents (Bakhtin 1981). Dialogue, in this sense, generates creative understanding by proposing unexpected questions and avenues of thought. The listener decodes the utterance, connects it somehow to their own life and world view, attempts to understand the reason it was spoken and how a third party might comprehend it, and considers how the utterance might respond to future utterances (Morson \& Emerson 1990).

Anthropologists, such as Vincent Crapanzano (1991) have used this notion of the dialogic or the "double-voiced word" in order to explore the workings of power within dialogue, with special attention to cross-cultural dialogue. In particular, Crapanzano's article, “The Postmodern Crisis: Discourse, Parody, Memory" provides important reflection upon two ways, within dialogue, to respond to the other: stylization and parody. He notes that parody and stylization are both double-voiced words; that is, words that are to be interpreted as the expression of two speakers. The words of one speaker are appropriated by a second speaker as the words of the first speaker but used for the second speaker's own purposes... (Crapanzano 1991: 437). Yet, while both parody and styli- 
zation evaluate, objectify, and attribute symbolic value to that discourse, stylization is typically read as a sign of submission or mutuality, whereas parody is a form of domination that needs critical or ironic distance. He argues convincingly that this sense of parody has important implications for cross-cultural exchanges because,

the other is recontextualized, most often,...stereotypically, and his words are treated as symptoms of that stereotyped contextualization. We understand and evaluate his words because we know 'where he is coming from.' This process leads to a practical engagement with, or manipulation of, the other...and precludes a real engagement with the other's point of view (Crapanzano 1991: 438).

It is a means by which to keep the other othered, rather than engaging in moments of ethical listening and speaking.

In the field of folklore, Bauman (1986, 1990 and 1993a,b), in particular, has advocated and made essential contributions toward understanding how Bakhtin's notion of the dialogic can provide an analytic framework for understanding folk performances and speech interactions. Relocating culture in the realm of social practice, as opposed to a structural-functionalist emphasis upon texts, meaning is conceived of as an emergent property of performance, produced through the mutual actions of the event participants. These participants are understood as socially positioned actors possessing differing degrees of power and authority that vary throughout the performance. Further, participants are recognized to be particular individuals with particular histories and connections with the other performance participants. Consequently, it is likely that any single event will yield a multitude of interpretations. In taking this approach, Bauman highlights the centrality of the actor in performance contexts and simultaneously opens new avenues for exploration based upon his use of Bakhtin's dialogic.

I believe one such avenue for folklore studies involves utilizing a large, relatively untapped area of Bakhtin's work, specifically his dialogic understanding of the self. Applying this dialogic conception of the self to the context of cultural performance acknowledges that a multiplicity of voices exist within a single performer, thus providing an extended structure for examining folklore. In addition, it adds to the study of folk performances by focusing upon the dialogic interaction between performance elements and the individual self. This attention to selfhood and self-consciousness calls critical attention to the problems of generalization and cultural relativism. It also accounts for individuals' ability to reflect on their choices of behavior and struggle with their own contradictions. 


\section{THE DIALOGIC SELF}

For Bakhtin, the issues surrounding the self are not merely psychological; rather, they encompass a wider philosophical perspective. Consequently, his theories of the self avoid invoking the unconscious, as explicated by Freud. Instead, he argues for a more complex understanding of a perpetually evolving consciousness. That is, within the domain of inner speech a complicated dialogue exists between multiple, socially heteroglot voices (Morson \& Emerson 1990). Bakhtin (1981: 346) argues that our ideological development is ... an intense struggle within us for hegemony among various verbal and ideological points of view, approaches, directions and values.

Thus, Bakhtin understood the self to be the combination of complex dialogues between a variety of voices and ways of speaking. These perspectives all articulate different world views and thus, selfhood is understood not as a single voice, but as a way of combining voices.

Our own discourse is gradually and slowly wrought out of other's words that have been acknowledged and assimilated and the boundaries between the two are at first scarcely perceptible (Bakhtin 1981: 345).

Interestingly, in this way he is able to address and critique traditional subjectobject opposition, arguing that there exists no stable world to which a self can be opposed. Instead, only our relationships with the world can make the outside world a concrete place. Thus, an object and its structure do not determine relationships; instead, relationships lead (Bakhtin 1979). This, in part, explains Bakhtin's rejection of structuralist approaches, articulated by scholars such as Saussure, which eliminated from analysis contexts of use.

In addressing the process of self-formation in both art and life, Bakhtin approaches the self through three related categories: I-for-myself, I-for-others, and the other-for-me (Bakhtin 1979). These categories are predicated upon the ideas of nonfusion and interaction. That is, the dialogic encounter does not result in a synthesis; rather, each keeps its integrity while it is enriched (Bakhtin 1986).

I-for-myself, which refers to the experience of looking from the inside out, focuses upon the continual process of trying to understand how others view the self. In this process, the ' $I$ ' searches for reflections of the self in images constructed by another. These images are obviously partial and never consolidate into a unified image; rather, they remain unfinalizable (Morson \& Emerson 1990). As Bakhtin (1984: 287) notes, 
a person has no sovereign internal territory, he is wholly and always on the boundary; looking inside himself, he looks into the eyes of another or with the eyes of another (author's emphasis).

However, it is important to note that individuals do not take on these "alien reflections"; rather, they are transcended by our inner selves. This process is considered constitutive of a healthy inner perspective. Conversely, Bakhtin (1979: 17) argues that if alien reflections ever do embed within us, they become dead spots of accompaniment, a brake.

The categories of I-for-others and others-for-me concern how others view me and how I view others. Implicit in this category is awareness that one never sees what others see when they look at the self. That is, each person possesses a particular field of vision that cannot be shared and does not include ourselves.

This other human being whom I am contemplating, I shall always see and know something that he, from his place outside and over against me, cannot see himself ... As we gaze at each other two different worlds are reflected in the pupils of our eyes ... to annihilate this difference completely, it would be necessary to merge into one, to become one and the same person (Bakhtin 1979: 23).

Inherent in the images supplied by outside others is insights that individuals cannot know about themselves. Bakhtin defines this extra knowledge as surplus and argues that this surplus allows another to complete an image of the self. In contrast, a person's own self image is never finalized - its position is constantly in flux.

This act is most valuable when one does not try to replicate the other. Rather, it is the production of something new that enriches each other's worlds (Morson \& Emerson 1990). In these cases, selves respond creatively to images provided by others and in this process they react to, learn from, and eventually transcend that image. This process continues through one's lifetime because while the image of another is finalized, the self's image is infinitely unfinalizable. These insights give rise to questions concerning how to understand the self in folklore performance. Beyond this, I would argue they are particularly relevant for understanding the performance acts of immigrants who live on the boundaries of identity, between here and there, us and them. 


\section{FOLKLORE AND IMMIGRANTS}

Folklore plays a crucial role in defining the identity of immigrant groups and individuals. The negotiation between self and other raises issues surrounding permanent and temporary identities, belonging and association. Dundes (1983: 250), who has conducted extensive research concerning identity formation and folklore, notes that,

any identity system is dependent on an individual's belief in his personal affiliation with certain symbols and with their meaning ... Folklore is perhaps the most important vehicle for the communication of a group's symbols.

It provides a means of self-reflection and self-exploration, serves as a symbol of identity, creates ties and defines boundaries. Folklore allows immigrants, who are confronted with a changed cultural environment, new world views, value systems, attitudes and symbol systems, to assess their new environment and begin to negotiate their place within it. The community and its culture begin to be defined by the synthesis of the old ways that are maintained and the new ways that are adopted.

These are not passive acts; rather, they are conscious decisions that significantly impact cultural landscapes (Kirshenblatt-Gimblett 1983). This recycling and continuous reshaping of folklore that occurs in community centers, households, schools, churches, etc. has been generally overlooked by folklorists, in favor of searching for authentic or uncontaminated pieces of lore. However, within the last decades, a heightened awareness of multilingual or multicultural competence and cultural diversity within folklore performances has become the focus of much analysis (Bauman 1986, 1987).

In addition, in the past, folklorists have tended to focus upon a shared sense of vernacular knowledge, custom, oral tradition and language in immigrant groups. This "in-group" approach focused upon the maintenance of boundaries dividing us and them (Barth 1969). In establishing a sense of identity, outsiders needed to be labeled, identified and shown to be different than one's own immigrant group. In such an approach, identity focused upon homogeneous and bounded representations that mistakenly portrayed immigrants, among others, as a discrete group of people. This corresponded to a general trend in folklore of seeing "the folk" as a unified entity. Bauman (1993a: xiv) partly attributes this to functionalist perspectives in anthropology that

reinforced the within group frame of reference on which traditionalist folklore theory has rested, and emphasized the role of folklore in sustaining group equilibrium and the maintenance of the social system. 
Within any ethnic group there are a vast range of competing ideologies, experiences, and orientations. While folklore is often used to communicate a shared sense of identity, it can also be used to express heterogeneity that continually negotiates group boundaries. Drawing from Bakhtin, I would argue that the borders of immigrant identity are infinitely resonating and shifting as multiple voices dialogue with other selves, cultures, histories and notions of community. This dialogic interaction, rather than leading to closure, is characterized by an openendedness that allows for the continual negotiation of group identity in the immigrant community. Different voices in a single event often foreground the interaction between cultural and social forces, calling attention to language as ideologically saturated, stratified, and representing multiple views of the world (Morris 1994).

It is this presence of different voices articulating cultural alternatives which characterizes the immigrant experience. Within folklore performances the immigrants' voices dialogue in highly visible ways with cultural elements, histories, artistic genres, ideologies, and social norms. Thus, no performance piece can be understood as a singular text; rather, it is a dialogic process that is connected to previous and anticipated performances and responds to alternative and challenging versions. Together, these dialogues between voices create a process of dialogic narration - both within the performance and between the performance and outside voices. Tellers and listeners within performance contexts

actively engage in an interpretive act to make 'the story' meaningful to themselves and relevant to their own life situations... There is a dialogue between autobiography and history as each person is aligned with the prevailing cultural tradition (Bruner \& Gorfain 1991: 182).

Thus, the content of performances is understood to be in dialogue with dominant ideologies, memories of past performances, personal experiences, as well as other self-relevant issues.

This seems particularly relevant for members of Indian-American immigrant communities, many of which formed recently, and thus, contain numerous first- and second- generation members who actively struggle with context, identity and tradition as the culture of their new home commingles with the forms and lore of their homeland. These communities were created primarily as a consequence of the 1965 immigration legislation which allowed up to 20,000 people from India to enter the US yearly (Saran 1985). The boundaries between old and the new, between us and them, are accented among members of such groups due to their existence in multiple cultural spheres. For Indian 
immigrants, these issues of identity and dialogue are highlighted in folk acts, as can be seen in the performance this paper considers - fatanas performed during a sangeet in Madison, Wisconsin.

\section{INDIANS AT HOME ABROAD}

Many of the larger Indian communities in America in urban centers such as New York, Chicago, Houston, and San Francisco contain plentiful regional concentrations, such as Gujarati, Punjabi, Bengali, Tamil, Malaylee, and Sindhi. Consequently, regional rather than national affiliations tend to draw individuals together into social groups. In contrast, Madison has remained relatively heterogeneous in terms of religious, ethnic and regional traditions, as well as social class, education, occupation and linguistic groupings. For this reason, national identity tends to be more of a connecting factor. However, at home regional affiliations still remain strong. A person whose family moved to Madison from Gujarat one or two generations ago may likely identify themselves as Gujarati, speak Gujarati at home as a primary language, and practice Gujarati customs. Relatives who have arrived more recently may reinforce these cultural distinctions, and reinject a practice of Gujarati language and traditions. For many, their identity refers not so much to a geographic place of residence, but to an elaborate network of culture, dialect, and social custom.

However, this is not to suggest that within Madison's heterogeneous community there is little cohesion. As a transnational national community, loyalties to an Indian homeland unite this diverse group on many levels, providing a collective sense of identity. Clearly, since people may share commitments without sharing beliefs, it follows that they may constitute a community without that community being based upon a consensus (Stromberg 1986: 13). But like all groups, they must struggle against their own discrepancies,

which lie precisely in the fact that they are composed of individuals, selfconscious individuals, whose differences from each other have to be resolved and reconciled to a degree which allows the group to be viable and to cohere (Cohen 1994: 11).

For these reasons, the answer to the question, "Who are you?" is negotiable for many Indian-Americans. While in a group of other Indians, a person might identify themselves regionally, as a Gujarati. On the other hand, while at work, surrounded by non-Indians, a person might choose to label themselves as Indian, Indian-American, Asian-American, Asian or just American. Strategic with 
their responses, the answer often depends upon who is asking the question and why. Visweswaran (1994) asserts that for many Indian immigrants and their offspring the hyphen between Indian-American calls attention to a state of mobile diaspora and the complicated choices involved in going and staying. The hyphen signals the desire (and the ability) to be both "here" and "there". Hussain also comments on the issue of unfinalizable boundary negotiation:

Hyphens are radically ambivalent signifiers, for they simultaneously connect and set apart; they simultaneously represent both belonging and not belonging. What is even more curious about a hyphenated pair of words is that meaning cannot reside in one word or the other, but can only be understood in movement (Hussain 1989: 10).

This emphasis on movement is echoed by Trinh Minh-ha (1991) who states that becoming Asian-American is a transient state where the hyphenated self and community is often repositioning itself in response to other cultures. For this reason, it is important to focus on the ways in which an immigrant's identity interplays and dialogues with the multiple identities that comprise the self. This is especially true when dealing with second- and third-generation immigrants who have little interaction with the "Old World", perhaps have married outside the immigrant group, and entered into American life from a different direction.

In the absence of the cultural environment available in India, one of the few ways children can become mindful of their Indian heritage, other than visiting India frequently, is to participate in organizations like A.I.A. (Association of Indians in America) or I.L.A. (Indian League of America). This is certainly the case in smaller Indian communities, like Madison's, that do not have community temples for worship or permanent cultural centers. Here, groups tend to organize bharatanatayam ${ }^{1}$ classes, Rasa dances or Diwali ${ }^{2}$ holiday festivities in schools or rented halls and attend smaller cultural performances held in private homes, such as the wedding sangeet I will turn my attention to next.

\section{AN APRIL SANGEET}

The sangeet performance under consideration was a relatively informal, private affair hosted by the Patwa family to celebrate the marriage of their daughter Asha $^{3}$ to Joe Anderson. Scholars at the University of Wisconsin, Arjun and Bharti Patwa were one of the first Indian couples to arrive in Madison during 
the "mid-60s' brain drain". They played a significant role in drawing together the initially small group of Indians and helping to construct a sense of community. The few transplanted families banded together, fostering a "close-knit friend circle"4 which included individuals representing various regions and religions. After three decades, the Patwas remain near the center of a much wider social network. While the number of Indian families, particularly Gujaratis, has grown, the Patwas' closest friends do not share their regional dialect or religious affiliation.

In general, the sangeet party is a pre-wedding celebration. The event is very popular in India amongst Gujaratis and Punjabis; indeed, originally it was a ritual practiced only in North Indian weddings. Now, however, it is conducted in Bengal and South-Indian weddings as well. Typically, the celebration for family and friends takes place a few days before the wedding. In some cases, the event is hosted jointly by both the bride's and groom's family. In others, the festivities take place separately. The scale varies as well. Sometimes the sangeet is quite elaborate and involves renting a large hall for garba ${ }^{5}$ dancing and a banquet and in other instances, it is celebrated in the home where a late supper is served. The smaller portion of this event is often called the "ladies sangeet," although today men may also participate. During this time, fatanas and other folk, love, and religious songs are sung.

For this sangeet the furniture in the Patwas' finished basement was pushed to one side and large pieces of white cloth were laid down for people to sit upon. Colored Christmas lights, arranged artfully in symmetrical designs, decorated the walls and fragrant sandalwood incense wafted through the air. A bar, providing wine, beer, soda and mixed drinks, was stocked and managed by one of Asha's uncles. Delicious samosas, kabobs, parotha and puri (breads), bataka (potato) and kubi (cabbage) vegetables, raita, papad, as well as barfi and seero (desserts) were prepared and served by Asha's extended family.

This wedding sangeet was significantly different in many ways from those this family typically hosted while living in Gujarat. Most generally, in Gujarat, sangeets were typically held during the second day of an elaborate three-day wedding event. However, in Madison, due to more rigid work schedules, the Patwas' sangeets are typically held in the evening. In terms of entertainment, in Gujarat, professional musicians were usually hired to sing and play instruments; however, in Madison, there is no one to hire. In any case, the Patwas preferred the personal aspect of having their friends sing, many of whom are accomplished musicians - one even having released an album of ghazals ${ }^{6}$ in India. 
Another important difference involves the composition and quantity of guests. In Gujarat, the guest list, numbering in the thousands, would include mostly Gujarati neighbors and friends. In contrast, in Madison, the nearly one hundred guests were primarily members of the Madison Indian community whose homes in India ranged from Gujarat to Bangladesh to Rajasthan to Bengal. In addition, the guest list included non-Indian friends and co-workers from the university, neighbors, bridesmaids, groomsmen, as well as relatives and friends of the groom.

Together, the Indian guests provided a significant portion of the entertainment. The program structure was flexible - some performers had arranged in advance to perform, while others merely informed Arjun of their interest to sing or dance and then waited for an opening to entertain. As with many Indian immigrant performances, the event pieced together a variety of different cultural genres and styles representing diverse regions and ethnic groups. The colorful mosaic that resulted could only be described as pan-Indian. Hindi film tunes, Rasa, garba and improvisational dance drew together audience and performers, so that often the two could hardly be differentiated. In sum, these individual performances created a dialogic narration that centered not only on familiar themes of marriage, gender, but also that of diaspora. The variety of regional, class, political, and religious backgrounds from the same national entity is reflected in forms of cultural expression such as music. The sangeet can be interpreted from all these points of view and from a collective diasporic community perspective. In this sense, the sangeet is a conversation exploring the intricacies of being diasporic.

The split between the observer and the observed was most visible during performances of Gujarati fatanas, classic Urdu ghazals and Marathi love songs which were sung in languages unfamiliar to a portion of the audience. During a series of recent weddings held by the Patwa family in Gujarat, there was no such cornucopia of regional songs. There, the format was almost totally Gujarati, focusing mainly on Rasa, garba, and the kinships songs surrounding marriage, such as fatanas. In Madison, however, the fatana comprised only one aspect of the overall sangeet. Nevertheless, it is the performance of these fatanas within this context, I will argue, that offers crucial insight into the dialogic interaction between the self and other, us and them, here and there. 


\section{FATANAS AND FAMILY TIES}

The new bride has come to the house.

She says she is the owner of the house.

She says - this belongs to me and that to you.

The new bride has come to the house.

She came quarreling with her mother-in-law.

She came harassing her father-in-law.

She came scolding her sister-in-law.

The new bride has come to the house.

She came asking for a separate kitchen.

Popular Gujarati fatana

Fatanas are typically performed by groups of women at ceremonies and gatherings before, during and after weddings. As a genre of folk song, fatanas can be found not only in Gujarat but in regions like Punjab as well. The songs themselves are characterized by a simple, repetitive rhythm and are primarily vocal in nature - sung without traditional instruments like flutes, drums, or trumpets. Their appeal rests in a catchy repetitive tune and simple and humorous lyrics where key phrases are emphasized. Learning how to sing these fatanas involves no formal training; it is a vernacular practice passed down through women within families. Wedding events inspire younger girls to learn these songs from a grandmother or aunt. Occasionally, the tunes have been written down in song notebooks but more often they simply have been memorized and so are passed from mouth to ear to mouth.

The women who sing these fatanas speak from particularly positioned spaces - as sisters, wives, aunts, mothers from different kinship, class, and castes. These insult songs range in potency from mild ribbing to blatant acerbic attacks on the bride, groom and their extended family, though no offense is usually meant to be taken. Some of the bawdier fatana have become associated with lower class status, and thus carry a stigma of provinciality. For this reason, women who are more educated, wealthy or reside in urban areas are less likely to sing these songs. ${ }^{7}$

However, as part of a marked event, fatanas are accepted as play by most people, leaving the insulted little recourse but to respond in kind with a fatana of their own. ${ }^{8}$

A stimulating contest of wit and words, this type of ironic ridicule breaks and challenges norms of conventional conduct and thought (see Mitchell 1992). 
Creating mayhem and deconstructing order through contradictory and exaggerated discourse, the fatana singer takes a critical stance in relation to dominant patterns of kinship and gender roles. Containing elements of hegemonic humor, fatana performances can be subversive or conservative; the former when it ridicules cultural norms, individuals, and ideas, the latter when it mocks the cultural deviance (Mitchell 1992).

For the anthropologist, this is the heuristic significance of studying clowning: the clown - a highly opinionated moralist - points baldly, and sometimes opportunistically, to the more prickly issues of everyday life and beyond. As such, clowning is criticism. (Mitchell 1992: 19)

In this sense, Bakhtin's notion of the carnival characterizes the performance of these fatanas. As a marked event, the singing of fatanas occurs in a safe zone in which marginal or non-official views of the world and kinship relations are sanctioned. Hierarchical positions are in a certain sense suspended, producing an atmosphere of more free and familiar interaction. It would seem that Bakhtin's notion of the carnival is most apparent within the content of the verses which, while mockingly reconsidering dominant ideologies, rarely proposes its abolition. This festive humor simultaneously accepts and denies its target; its nature is both harsh and engaging. Targeting everyone, ${ }^{9}$ all the world, or specifically in this case, all kinship relations are held up and made humorous.

Two broad categories of fatanas exist, both commenting upon the complexities of Gujarati kinship ideologies and the shifting boundaries between natal and conjugal ties at the time of marriage. The first type of fatana addresses the internal relations of the natal family and are sometimes sung at the expense of those "others" who married into it, such as sister or brother-in-law. These songs highlight and celebrate the intimate solidarity and bonds between sisters, brothers, daughters, sons, mother and father. In particular, because of the significant ties between sisters and brothers in Gujarati culture (as typified by Raksha Bunden and Bhai Beeg holidays) fatanas are often sung to remind brothers of their responsibilities to their sisters and daughters, as the following fatana illustrates:

The moon is revolving rapidly to brighten the sky at night and Arjunbai is running around for his daughter's wedding. 


\author{
All your gold will rot, \\ Your money will be rusted, \\ All your diamonds will lose their luster \\ And all your pearls will have cobwebs. \\ Instead, spend all this money for your daughter's wedding.
}

Performance situations framed in contrast to everyday practice are a resource that can often provide a vision of power relations (Bauman \& Briggs 1990). The opportunity to express ideas about kinship relations in an ironic, rude or critical manner, under the auspices of a joke, not only provides a chance for women to promote positive and assertive self-images, but it also supplies a forum for voicing concerns in a subversive manner (see Trawick 1986, Narayan 1986, Hansen 1992, Raheja \& Gold 1994).

The second type of fatana are sung most often on the day of the wedding, after the groom's extended family reaches the prospective bride's home. For example, while initially waiting for the bride and her family to greet them, individuals and groups of women from the groom's family often loudly sing fatanas which remark rudely upon individuals in the bride's family or which generally insult the prestige of the family as a whole. One such popular fatana refrain is:

When in your house you did not have sugar,

Why did you invite this wedding party?

When you did not have enough chairs,

Why did you invite us accountants?

When you did not have enough kharek ${ }^{\mathbf{1 0}}$

Why did you invite all these wealthy people?

When you did not have enough rugs on which to lie

Why did you invite all these businessmen? ${ }^{11}$

If the women of the bride's house know how to sing fatanas they will respond with a similarly insulting verse. These fatanas can continue to be sung even after the families reach the wedding hall and well into that day.

As performance of fatanas involves taunting and insulting kin, a relatively self-confident and uninhibited personality is required; and not surprisingly, the best performers are those who play to the audience, singing boisterously with vivacious spirit. In addition, accomplished fatana singers employ facial and bodily gestures, as well as vocal tone to highlight language and add meaning to their performance. The major refrains of these songs are often repeated by a chorus who echo the fatana leader in tone, style and intensity. 
Singers are also continuously pairing jokes and barbs with the name of kin. In this sense, the fatana are used as templates to which innovative twists and personalized information can be added. ${ }^{12}$ Due to this improvisational aspect, there is ample room for individual play and personal engagement and consequently, singers also need to possess creative abilities and a sharp wit. Like the ginnewas Abu-Lughod (1986) discusses in Veiled Sentiments, this verbal dexterity is commonly expressed through borrowing, combining and altering pieces of popular culture, favorite metaphors, classic images, and the like into verses that form the song. With these issues in mind, I will now focus on two of the fatanas performed on that April evening and the individuals who produced them.

\section{MEENA AND RAJAN}

Meena, the eldest sister of Arjun Patwa, grew up with her four brothers and one sister in a small Gujarati village. While her father was a well-to-do landowner and farmer, she received only a grade school education, after being abruptly pulled from school following the death of her mother. At twelve, she took over her mother's responsibilities, caring for her young brothers, preparing meals and managing the household. As her brothers grew and moved to a nearby city for education, she moved with them, spending her late adolescence in more urban surroundings. At sixteen she married a young man whose family owned land, leading her back to the rural surroundings of a town very much like her birthplace, where she raised three children and ran a 'general store'.

During the late 1960s three of her brothers immigrated to the United States. Motivated by a concern for her children's future, visas were requested, green cards granted, and in 1991, Meena, her husband and their youngest son immigrated to the United States, initially living in the Chicago area. There they found a large Gujarati community with whom to share travails and stories of home. While Gujarat was missed, the surrounding contained a taste of the familiar, particularly Devon Avenue with its spice shops, sari bazaars and Indian restaurants.

After her husband unexpectedly passed away in 1994, Meena and her son, Vikrum, moved to Madison to live with Arjun and Bharti. The transition was somewhat difficult; her early departure from school left her with only a rudimentary understanding of English and a limited training in formal Hindi, making it difficult for her to communicate with the diasporic community in Madi- 
son. Compared to Chicago, she felt isolated. There was no one with whom she could share her religious convictions or traditional outlook besides her son.

Meena often hints that she would move back to India if she could, but concern for her children's prosperity compels her to stay. In response to the challenges of life in Madison, she has withstood attempts by her brother to "Americanize" her; instead she continues to perform daily religious rituals pujas for everyone's health and wellbeing, cooks and eats only vegetarian Indian food (a practice long abandoned by most other immigrated members of the Patwa family), and avidly contemplates religious texts. Meena also bears the mantle for many of the traditional rites and songs. She consults the horoscope, guides the family through traditional elements of holiday festivities, and shares her stories and songs.

In particular, Meena is considered by family and friends to be an excellent fatana singer. Her wide repertoire, enthusiastic delivery, and improvisational alertness mark her as "particularly gifted" performer. She acquired some of these talents by attending a lifetime's worth of weddings, observing other women performing and eventually participating herself as an adolescent. Her style is boisterous, with a flair for creative flights of exaggerated mocking, combined with a strong voice. Meena acknowledges that not everyone appreciates her skills - humor and laughter are complex cultural phenomena and not everyone always gets the joke. She feels this is particularly true for the young Indian-Americans who matured in America, as they miss associations drawing upon Indian cultural images and forms.

Rajan, the youngest son of Arjun and Bharti, is just this type of "young Indian-American." The only member of his family born in America, he was raised in Madison, growing up in an environment with few Gujaratis. His exposure to his native culture emerged from a combination of 'second-hand' experiences: Gujarati spoken over the dinner table, brief trips to visit his more traditional cousins and the occasional A.I.A. events. Visits to India were infrequent, the most recent trip being twenty years before. Consequently, he never learned to read or write Gujarati, only to speak it. His oldest brother and sister, who arrived in America in their teens, retained more of their heritage; for Rajan, the issue was not retention, but exposure.

Growing up, Rajan's friends and interests reflected a decidedly American leaning. He collected beer cans and played baseball, not cricket. He dated in high school against his parents' wishes and only counted one Indian woman among his girlfriends. Caught between his more traditional Indian parents, grandmother and siblings on the one hand and his American peers and experiences on the other, he experienced two cultures, fully belonging to neither. 
His strongest link to India was his maternal grandmother, who lived with the Patwa family until her death in the early 1990s. Only speaking Gujarati, she would convey stories of India and her childhood, tales of Rama and Krishna and bits of wisdom from her hero, Mahatma Gandhi. Rajan credits this relationship with forcing him to learn to communicate in his parents' tongue and appreciate his Indian heritage.

Today, Rajan still feels like he lives on the boundaries of both mainstream American and Indian-American culture. Constantly adjusting his orientations to meet cultural expectations, Rajan struggles to reconcile his image of himself with those of others. While his sense of duty to his family is one of his highest priorities - in his opinion an Indian attribute - he values his independent disregard for certain Indian norms. Among the most relevant of these was his choice to marry an Anglo-American. As the first member of his family to blur the lines of his identity in this way, he often feels the need to prove he is "still Indian" - to retain his involvement with his family and his culture.

\section{WORMS, BEAT-UP CARS AND WILD PLANTS}

In their performances, Meena and Rajan negotiated a creative space for themselves within their perceptions of the broader sangeet. For both, their performances were colored and shaped by how others, outside the aesthetic act, appeared to them. In dialogic interaction with these conceptions was their conscious, artful creation of a finalizable self for those outside observers. This reflexivity goes beyond that as understood by scholars such as Giddens (1984);13 rather, in Bakhtin's framework the self's powers of creativity and motivation are highlighted. An examination of the texts and performances of these fatanas renders this process more visible.

Meena's fatana was performed near the height of the sangeet, after dinner had been served and more than a few drinks had been poured. Sitting crosslegged, in front of a crowded floor of people, Meena, smiling widely, signaled repeatedly for silence and passed a conspiratorial side glance at Asha. This done, she loudly began to sing the following song, gesturing emphatically towards each person she addressed. In the background, almost unnoticed, her sister, Reena and sister-in law, Parula served as a chorus:

The relatives and the groom's party are present for the wedding. Among them Asha's brother stands out like a diamond in a ring, 
While Joe's brother looks like a worm in a flowerpot. Asha's mother spreads fragrance like a well-groomed flower bed, While Joe's mother looks like a beat-up and wrecked car. Asha's sister looks like a fully bloomed climbing vine, While Joe's sister looks like a wild plant in a rose bed.

As each line was sung, Arjun translated the words from Gujarati to English for the enlightenment of Joe and his family, who laughed in delayed response to the unexpected barbing. Throughout the room, those who understood the meaning shared their understanding with others less linguistically proficient. The audience responded favorably to the song, though not with the same vigor that followed the inclusiveness of a popular Hindi film song or the kinetic force of a Rasa or garba.

I discovered in interviews with Meena after her performance that she had actively contextualized this fatana performance not only against her past performances and acclaim in Gujarat, but also in relation to the variety of performers, performances and audience members at this particular sangeet. Consciously adjusting the fatana, she sang in response to her understanding of her audience; particularly, Meena expressed concern about being looked upon as unsophisticated by Indian community members who she perceived as educated and of high class status. This calls attention to the underlying and often masked power relations within community dynamics. Thus, though songs in her repertoire included far worse castigating insults concerning weight, marital status, height, and sexual potency, Meena, well aware of the stigma attached to the bawdier selections from this genre, purposefully selected a fatana which would be viewed a less offensive and provincial. Indeed, when pressed, she reminded me that her performance directly followed an Urdu ghazal sung by a South-Asian scholar associated with the university. In dialogic response to this contextual feature, Meena offered a version of herself in the performance that actively and creatively forwarded socially desired aspects of her personhood.

However, her performance was not only a strategic response to context and structure. Indeed, a focal aspect of her choice and action concerned the satisfaction she received from ingeniously sharing her art and positioning herself with the Patwa family. When asked what the fatana meant to her, or how she felt when she sang it, she repeatedly answered that much of the meaning and emotion attached to the experience centered on issues of personal satisfaction, belonging and the pleasures of artistic creation. Again this view of the selfcreation differs from Goffman's (1959) rather reactive conception of self. From his view, presentations of self [are] dictated by strategic considerations emanat- 
ing from structural context, rather than from individual creativity and imagination (Cohen 1994: 27). Clearly, Meena's fatana performance was not only a reaction to a social context and an understanding of others, but also contained features of self-creation and artistic potential.

Most specifically, her choice of words in the fatana and her mocking tone positioned her as a clown who laid bare the boundaries between natal and conjugal homes. The imagery and the similes she constructed powerfully conveyed this point, juxtaposing the brothers, mothers and sisters of the two families in order to raise up her own, while denigrating the other. By comparing a diamond to a worm, a groomed flower bed to a wrecked car and a climbing vine to a wild plant, she asserted the cultivated and refined status of her own family, while suggesting a lesser position for those not yet members. However, as Bakhtin notes, this carnivalesque humor is grounded in a sense of familiarity, in which rudeness can be understood as a form of affection. Rich and contradictory, the "laughing word" celebrates ridicule of the serious word and thus, the spirit of carnival laughter is generally therapeutic and freeing, as it demolishes fear and piety before an object (Bakhtin 1981: 23). In the ambivalence of carnival laughter, ridicule and defilement are always juxtaposed against acclaim and celebration. This laughter emphasizes the messiness of life as multitudes of dialogues continuously intersect creating pure possibility. Indeed, as Meena divulged after her performance, one of her aesthetic goals was to engage the Andersons through humor and, thus, include them in the event and the broader community.

However, despite her feelings of goodwill, Meena does not see the boundary between the two families as permeable. As her opening line suggests, she recognizes a split between the natal from the conjugal - one group is viewed as relatives (which would include extended family), while the groom's party is understood as separate. The internal patterning and formal structure of the song highlight the opposition of in-group and out-group. The goal of this discourse is not to insult the Andersons, but instead to creatively reinforce her bond with her own family.

This artistic performance also positions Meena as a bearer of Gujarati traditions. Very few of the guests in attendance knew how to sing a fatana, let alone to perform one with the linguistic play, colloquialisms, and nonverbal dynamics Meena displayed. Thus, in the process of presenting this song, she also presented an image of herself as specifically Gujarati, as opposed to the more diasporic pan-Indian that was so prevalent in the Madison Indian community. 


\section{"RULES A HUSBAND SHOULD KNOW"}

Immediately following Meena's fatana, Rajan rose to offer his contribution to the evening. As was mentioned previously, men are not typically performers of fatana. However, in this sangeet, Rajan participated in the celebratory banter by transforming and actively recontextualizing ${ }^{14}$ a piece of American office folklore so that the audience interpreted his performance through the fatana frame. That is, while Rajan's performance is clearly not a fatana, it is understood within this tradition. Weaving an intricate web of verbal anchoring for his discourse, Rajan's fatana intersected and dialogued with the fatana tradition, as well as the specific fatanas performed at this sangeet. It is in this space that he performed his "Rules a Husband Should Know":

Rajan: "I have a little bit of advice for my new brother-in-law here...anyone who knows me, I'm not going to subject you to my singing. (Audience cheers.) These are some bits of wisdom my brother passed on to me."

Mona: "Uh oh!” (Rajan's eldest sister)

Rajan: "Unfortunately, he didn't do it four years ago when I got married. So, I'm going to do Joe the favor of giving him these bits of advice now. Many of you may be familiar with these little bits of wisdom either through experience or from hearing them. But they're basically rules a husband should know."

Audience: (Lots of laughing and clapping.)

Rajan: "Now here are the rules. Number one, the wife makes all the rules."

Audience: (The women hoot and clap. The men also laugh and clap, but some boo.)

Rajan: "The second rule is the rules are subject to change at any time without prior notification from the wife."

Audience: (Laughter.)

Rajan: "The third rule is - if the wife suspects that the husband knows the rules, she immediately changes some or all of the rules."

Audience: (Laughter and clapping.)

Rajan: "The fourth rule is the wife is never wrong.

Audience: (Laughter.)

Rajan: "And that plays into the fifth rule which is - if the wife is wrong, it is because of a flagrant misunderstanding which is a direct result of something the husband did. 
Audience: (Lots of clapping. Some women yell out, "Yeah, yeah!")

Rajan: "Now, it gets a little more complex. If rule number six applies, the husband must immediately apologize for causing the misunderstanding."

Audience: (Lots of laughing and clapping. The groom and his father-in-law laugh and shake hands.)

Asha: "You better mark that one" (speaking to her fiancé.)

Rajan: "Now that leads me to the seventh rule, which is the wife can change her mind at any time without warning."

Audience: (Some laughter.)

Rajan: "Now the next rule is the husband must never change his mind without written consent from the wife.

Audience: (More laughter and clapping.)

Rajan: "The next rule is the wife has every right to be angry or upset at any time."

Audience: (Laughter.)

Rajan: "The husband must remain calm at all times, unless the female wants him to be angry or upset."

Audience: (Lots of laughter.)

Mona: "You remember that."

Rajan: "The next rule is the wife must under no circumstances let the husband know if she wants him to be angry or upset. He is supposed to know this for himself."

Audience: (Laughter.)

Rajan: "I'm going to skip the next rule..."

Minal (family friend): "No, no, no! No skipping rules without asking!"

Rajan: "Sorry! And as the first rule indicated, I must now go with what she says! If the wife has P.M.S., all of the rules are null and void.”

Audience: (Lots of laughing, clapping and hooting.)

Rajan: "And the final rule is, any attempt to document these rules by a male, could result in bodily harm to the male and the immediate change in the rules by the female. Congratulations you two. Here's a copy. Thank my brother, he is the one who gave them to me." 
In this discourse, one immediately sees Bakhtin's notion of the 'turnabout' where the world is twisted inside out - power in marital relationships belonging solely to the wives. While in an American office setting, this text would most likely dialogue with mainstream American notions of gender relations. However, in this sangeet Rajan reframed his text so that the discourse was more directly focused upon his soon-to-be brother-in-law. In particular, this appropriated discourse was reoriented so that it celebrated the bond between sister and brother, while simultaneously roasting Joe. In true fatana form, Rajan raised up his sister at the expense of her fiancé, predicting that Joe would serve Asha, "The Rule Maker".

Of course, as with Meena's fatana, the intent of the performance was not to alienate Joe or to offend his family; instead, the aim of Rajan's ribald humor was to render the boundaries between kin and outsiders plain, while simultaneously drawing the members of the outgroup closer. The result was a complex intersection of dialogues that not only addressed issues of marital relations and highlighted clashes between gender, but also brought to the foreground issues of diasporic Indian identity and kinship.

Rajan's performance contextualizes him in various ways as diasporic. On the most general level, he distinguished himself by performing the only piece based on a Western text. His narrative was also the only non-musical performance that evening. Rajan's comment, I'm not going to subject you to my singing, drew salient linkages with the previously sung fatana, placing the two in dialogic interaction. This tactic established a place for his text within the larger immigrant performance that otherwise was composed entirely of Indian songs and dances. He reflexively presented obvious thematic parallels between his text and the fatanas by addressing the issues of marriage, family and ridicule.

Rajan blatantly drew upon this genre in a creative manner, adopting the fatana singers' mocking and liberated tone; he consciously engaged his text in dialogues not only with the fatanas performed at this event but with the history of the fatana tradition and the memories of fatanas performed at prior sangeets. He used his knowledge of the genre to play with the conventional form, content and other performance expectations. As he later stated, This was a large part of what was funny about my performance. I was a man doing an American fatana. The audience, recognizing the parallels he was drawing, also contextualized and understood his performance as a form of fatana. Meena, the resident expert in these matters, commented that since the piece used humor and insult to distinguish between natal and conjugal boundaries, it could certainly be understood as a fatana. This was clearly apparent after his performance, as audience members talked amongst themselves about their thoughts on "The Rules" and teased Joe about his subordinate role. 
This assessment by the wedding guests is, on some levels, somewhat concerning. Certainly, one can reflect back to Crapanzano's (1991) concern with the dominating potential of parody and the way that it appropriates and essentializes the voice of the other. Yet, I would argue that Rajana's choice had much more to do with his personal diasporic experience - specifically, his limited repertoire. That is, Rajan's unwillingness to sing traditional Gujarati folk songs had little to do with his musical abilities. Rather, he is simply unfamiliar with many folksongs. This gap in his cultural repertoire positioned him ambiguously within the performance event. To a certain extent, he often perceives himself in these performance contexts as somewhere between American and Indian, Midwestern and Gujarati and, consequently, frequently has problems locating himself within traditional forms. In this case, he had an opportunity to communicate an identity that transcended this boundary by bending a traditional Gujarati genre in unexpected directions to fit with a piece of American lore. As Rajan later stated, his unfamiliarity with Gujarati folk songs and other cultural markers positions him as a second generation Indian immigrant in the Madison community, since many of the other second generation children are also unable to perform Indian folk pieces due to language constraints or a lack of cultural education. Yet, by drawing on the fatana genre, he created an expression of his diasporic identity, presenting an I-for-others that displayed an image of himself that is both Indian and American, without favoring one over the other.

Rajan also contextualizes his performance by attributing the text to his elder brother in both the introduction and the conclusion of his narrative. Having said this, Rajan pulled the text away from the self he was constructing for the consumption of the audience. He distanced the rules from his personal point of view, creating an aura of ambivalence. This uncertainty about Rajan's relationship to the words being spoken was further enhanced by his mocking, yet simultaneously appreciative tone. The conflict between the narrator's voice and the voices in the text create complex interrelationships for the audience and performer to explore.

This only adds to the 'potential' of Rajan's creative act. By leaving the interpretation open, he takes on a carnivalesque tone. His performance inverts the traditional sense of manipulation and disparity in marriage that is often a central theme in Indian women's folklore and folksongs. In this case, the images are reversed and the husband is the one who must consistently submit and appease. Thus, Rajan's performance enters into dialogues with traditional Hindu and folk ideologies and conceptions of the marital relationship. Specifically, one rather obvious example is the Hindu notion of the pativrata - the dutiful, docile wife - that is embodied in the popular folk characters Sita and Savitri. 
The women in the audience responded positively to the representation of an assertive and domineering wife. Indeed, a number made verbal responses that embraced the image, such as the bride who comments to her fiancé, "You better mark that one." Another example is Minal's command that rules can not be skipped. Their words become part of the performance event as a whole. These remarks call attention to the fact that internally generated images and dialogues, reflecting a hypothetical "other" point of view, can also provide profitable opportunities for reflection.

\section{CONCLUDING REMARKS}

As these ethnographic sketches demonstrate, the application of Bakhtin's conception of the dialogic and the self to a performance-centered approach to folklore provides a dynamic framework for attempting to understand folk performance. Bakhtin's notion of individuals as dialogic in relation to themselves, others and cultural forms, creates vast opportunities for ethnographic exploration. This framework can provide an abundant amount of ethnographic detail concerning any single performance. In the construction of this ethnography of the particular, I was required to draw dialogic linkages between history, ideology, culture, folk genres and self conceptions, with particular attention to context, performance and texts.

Clearly, this framework has applicability beyond the immigrant folk performances with which this paper concerns itself. However, the study of folklore production by immigrant groups and selves seems to be a particularly appropriate area for employment. In immigrants' struggles with the nature of their identities and feelings of ambivalence towards elements of their diverse cultural repertoire, the role of the self is highlighted. These individuals are continually forced to make meaning of themselves on the basis of often contradictory, cultural forms, ideologies, familial expectations, friendship ties, and internal states. Cultural performances, as sites of multiple and shifting discourses, are places where imagination is fueled by the fluid intersections and contradictions of these elements. This elusive, creative process provides the possibility for the self to be presented in a myriad of different ways, at different times, for a single individual. This emphasis upon crafting one's self is tempered by an understanding that identities, no matter how strategically employed, are not always chosen, but are in fact constituted by relations of power always historically determined (Visweswaran 1994: 8). By focusing on this multiplicity of dialogues, a folklorist can potentially move beyond the performance itself and address issues of the self. 
The converging theoretical streams synthesized here suggest the need for key alterations in ethnographic pursuits. In particular, as folklorists we need to move beyond the sometimes simplistic applications of practice theory that characterizes a variety of current ethnographic work. While practice asks us to go beyond the text to the act, I am calling for a movement that accommodates and unifies the self within the act. While this certainly applies to folklore, a similar approach could be modified and applied to a variety of ethnographic settings. The challenge of such an application lies in the ethnographer's ability to grasp the dialogues within the performance and subject they are attempting to understand. The process is painstaking and fraught with difficulties, not the least of which centers around the issues of privacy and the ethics of disclosure. However, I believe this approach offers substantial benefits, particularly for scholars interested in immigrant practices.

\section{Gujarati fatanas}

(Sung when the groom's party meets the bride's party at the wedding)

Ghar man nhotu nanu (money), tyare shid lidhutu tanu (occasion)

Ghar man nhoti khad (sugar), tyare shid tedyuti Jan (wedding party)

Ghar man nhoti khurshi (chair), tyare shid tedyata munshi

Ghar man nhoti kharek (dates), tyare shid tedyata parekh

Ghar man nhota Lota (pitchers), tyare shid tedyata mota

Ghar man nhota takiya (pillows), tyare shid tedyata shethia

Ghar man nhoti sopari (bettlenuts), tyare shid tedyata vepari

Ghar man nhoti jajam (rug), tyare shid tedyutu sajan

Ghar man nhoti Gagar (waterpot), tyare shid tedyata nagar

$* * *$

(Sung by the groom's party)

Nanavati re sajan bethu mandve

Lakhopati re sajan bethu mandve

Jeva viti mana hisa, aeva var-raja na vira (brothers)

Jeva chhand mana kida aeva kanya na vira

Jeva vadi mana amba, aeva var-raja na kaka (uncle)

Jeva vanvagda na vela, aeva kanya na kaka

Jeva fulvadni velo, aevi var-raja ni behno (sisters)

Jeva vanvagda ni velo, aevi kanya ni behno

Jevi fulifuli fulvadi, aevi var-raja ni madi (mother)

Jeva pagdi na aeta, aeva var-raja na dada (grandfather) 
(Sung by aunts)

Chando fare re utavado, chandi tare re kaje

Bapa fare re utavada, dikri (daughter) parnavvane kaje

Jaja sona sadi jashe, ruppiye vargyo kat

Jaja hira jarkhu padya, motiye vergya jada

Ae dravya kharcho (girl's father's name), dikri parnavvane kaj eg sanabhi

$* * *$

(Sung by bride's party to the best man)

Ae vartara anvar man na dam

Anvar lajamado ne, aena khissa khaikham

Nak jane nariyer, ane najar tukitach

Kan jane supala, ane kamar gai juki

Hath pag dordi, ane pet gagrdi

Thaine janayyo, than than nachto

Varne lajavto, ne jan ne pan lajavato

Aene jraye pade na gam

\section{Translated Gujarati fatanas}

When in your house you did not have sugar

Why did you invite this wedding party

When you did not have enough chairs

Why did you invite us, accountants

When you did not have enough kharek

Why did you invite all these wealthy people

When you did not have enough rugs on which to lay

Why did you invite all these businessmen?

$* * *$

The relatives and the groom's party are present for the wedding.

Among them

Asha's brother stands out like a diamond in a ring,

While Joe's brother looks like a worm in a flowerpot.

Asha's mother spreads fragrance like a well-bloomed flower bed,

While Joe's mother looks like a beat-up and wrecked car. 
Asha's sister looks like a fully bloomed climbing vine,

While Joe's sister looks like a wild plant in a rose bed.

$$
* * *
$$

The moon is revolving rapidly

To brighten the sky at night

And Arjunbai is running around

For his daughter's wedding.

All your gold will rot,

Your money will be rusted

All your diamonds will lose their luster

And all your pearls will have cobwebs

Instead, spend all this money for your daughter's wedding

$* * *$

Your best man is worthless

(Spoken to the best man)

You don't have any money in your pocket

Your nose is like a coconut and you can't see far

Your back is bent

Your hands and legs are like a thin piece of rope

You have a potbelly

The groom's party is ashamed of you for the way that you are dancing

You are unable to understand a thing!

$$
* * *
$$

The new bride has come to the house.

She says she is the owner of the house.

She says - this belongs to me and that to you.

The new bride has come to the house.

She came quarreling with her mother-in-law.

She came harassing her father-in-law.

She came scolding her sister-in-law.

The new bride has come to the house.

She came asking for a separate kitchen. 


\section{COMMENTS}

1 A classical dance form originating from Southern India.

${ }^{2}$ Major Indian festival.

3 At the request of the participants, all the names in this paper are pseudonyms.

${ }^{4}$ A phrased used regularly by both Arjun and Bharti.

5 An Indian dance that originated in the Gujarat region.

6 A poetic form, a poetic expression of both the pain of loss or separation and the beauty of love in spite of that pain.

7 The prominence of fatana is decreasing in weddings in India, as young people prefer the more participatory events, such as Rasa and garba, which involve dancing. As a result, many young women do not learn to sing fatana, and the pool of women who carry the tradition may be decreasing.

8 In explicating the function of fatanas, Viru, one of Asha's adolescent cousins, compared fatanas to African American "Your Mama" jokes. He offered examples of this parallel by drawing on some of his favorites: "Your mama's so stupid she failed her blood test"; "Your mama's so fat people jog around her for exercise"; and "Your mama's so skinny she turned sideways and disappeared". In both cases, he felt, participants devote a lot of attention to the degree of insult and adjust their response accordingly. Moreover, in each form, it works best if there are at least two participants bantering.

9 The inclusive aspect of this immigrant performance deserves special note. Some of the fatana singers later interviewed made mention of the fact that in Gujarat, men often did not have much involvement in the fatana performances. Often they were engaged elsewhere in other aspects of the marriage ceremonies. Their level of participation and interest in the women's fatana performances in this circumstance is a new development that has interesting ramification on performance style and content. This, again, will have to be left for another paper.

10 A dried date.

${ }^{101}$ While the rhyming couplets of the fatana are lost in the English translation, the essence of the meaning remains.

12 This is reminiscent of the songs Trawick discusses in her article, "Internal Iconicity in Paraiyar Crying Songs" (1986).

${ }^{13}$ For a more detailed explanation, see Cohen (1994).

${ }^{14}$ For a detailed description of the term "active contextualization", see Bauman 1990. 


\section{REFERENCES}

Abu-Lughod, Lila 1986. Veiled Sentiments: Honor and Poetry in a Bedouin Society. Berkeley \& Los Angeles: University of California Press.

Appadurai, Arjun 1990. Disjuncture and Difference in the Global Cultural Economy. Public Culture. No. 2, pp. 1-24.

Bakhtin, Mikhail 1986. Speech Genres and Other Late Essays. Caryl Emerson and Michael Holquist (eds.). Transl. by Vern W. McGee. Austin: University of Texas Press.

Bakhtin, Mikhail 1981. The Dialogic Imagination: Four Essays. Michael Holquist (ed.). Austin: University of Texas Press.

Bakhtin, Mikhail 1979. Avtor i geroi v esteticheskoi deiatel'nosti [Author and hero in aesthetic activity]. In: M. M. Bakhtin Estetika slovesnogo tvorchestva. The 1979 Russian Collection. Moscow: Iskusstvo, pp. 7-180.

Bakhtin, Mikhail 1968. Rabelais and His World. Transl. by Helene Iswolsky. Cambridge, Mass.: MIT Press.

Bakhtin, Mikhail 1963. Problems of Dostoevsky's Poetics. Ed. and transl. by Caryl Emerson 1984. Minneapolis: University of Minneapolis Press.

Barth, Fredrik 1969. Ethnic Groups and Boundaries: The Social Organization of Culture Difference. Boston: Little Brown.

Bauman, Richard (ed.) 1993a. Folklore and Culture on the Texas-Mexican Border. Austin: University of Texas Press/CMAS Books.

Bauman, Richard 1993b. The Nationalization and Internationalization of Folklore: The Case of Schoolcraft's "Gitshee Gauzinee". Western Folklore, Vol. 52, No. 2/4, pp. 247-269.

Bauman, Richard 1990. Contextualization, tradition, and the dialogue of genres: Icelandic legends of the Kraftaskald. In: C. Goodwin and A. Duranti (eds.). Rethinking context: Language as an interactive phenomenon. Cambridge: Cambridge University Press, pp. 125-145.

Bauman, Richard 1986. Story, Performance and Event: Contextual Studies of Oral Narrative. Cambridge: Cambridge University Press.

Bauman, Richard \& Briggs, Charles L. 1990. Poetic and Performance as Critical on Language and Social Life. Annual Review of Anthropology, Vol. 19, pp. 59-88.

Bruner, Edward \& Phyllis Gorfain 1984. Dialogic Narration and the Paradoxes of Masada. In: Edward M. Bruner (ed.). Text, Play, and Story: The Construction and Reconstruction of Self and Society. Washington, D.C.: American Ethnological Society, pp. 5679 .

Chambers, Iain 1994. Migrancy, Culture, Identity. London: Routledge.

Cohen, Anthony 1994. Self Consciousness: An Alternative Anthropology of Identity. New York: Routledge.

Crapanzano, Vincent 2004. Imaginative Horizons: An Essay in Literary-Philosophical Anthropology. Chicago: University of Chicago Press.

Crapanzano, Vincent 1992. Hermes Dilemma and Hamlet's Desire: On the Epistemology of Interpretation. Cambridge Mass. \& London: Harvard University Press. 
Crapanzano, Vincent 1991. The Postmodern Crisis: Discourse, Parody, and Memory. Cultural Anthropology. Vol. 6, No. 4, pp. 431-446.

Crapanzano, Vincent 1980. Tuhami: Portrait of a Moroccan. Chicago: University of Chicago Press.

Crapanzano, Vincent 1977. On the Writing of Ethnography. Dialectical Anthropology. Vol. 2, No. 1, pp. 69-73.

Dundes, Alan 1983. Defining Identity through Folklore. In: A. Jacobson-Widding (ed.) Identity: Personal and Socio-Cultural, A Symposium. Uppsala: Uppsala Studies in Cultural Anthropology. Vol. 5, pp. 235261.

Giddens, Anthony 1984. The Constitution of Society: Outline of a Theory of Structuration. Cambridge: Polity Press.

Goffmann, Erving 1959. The Presentation of Self in Everyday Life. Garden City, New York: Doubleday.

Hansen, Kathryn 1992. Heroic Modes of Women in Indian Myth, Ritual and History: The Tapasvini and the Virangana. Annual Review of Women in World Religions, Vol. 2, pp. 1-62.

Hill, Jane H. 1995. The Voices of Don Gabriel: Responsibility and Self in a Modern Mexicano Narrative. In: D. Tedlock and B. Mannheim (eds.) The Dialogic Emergence of Culture. Urbana: University of Illinois, pp. 97-147.

Hussain, Nasser 1989. Hyphenated Identity: Nationalistic Discourse, History, and the Anxiety of Criticism in Salman Rushdie's Shame.Qui parle? Literature, Philosophy, Visual Arts, History Vol. 3, No. 2, pp. 1-18.

Kirshenblatt-Gimblett, Barbara 1983. Studying Immigrant and Ethnic Folklore. In: R. M. Dorson (ed.) Handbook of American Folklore. Bloomington: Indiana University Press, pp. 39-47.

Minh-ha, Trinh T. 1991. When the Moon Waxes Red: Representation, Gender and Cultural Politics. New York \& London: Routledge.

Mitchell, William 1992. Clowning as Critical Practice: Performance Humor in the South Pacific. Pittsburgh: University of Pittsburgh Press.

Morris, Pam (ed.) 1994. The Bakhtin Reader: Selected Writings of Bakhtin, Medvedev and Voloshinov. New York: Edward Arnold.

Morson, Gary Saul \& Emerson, Caryl 1990. Mikhail Bakhtin: Creation of a Prosaics. Stanford: Stanford University Press.

Narayan, Kirin 1986. Birds on a Branch: Girlfriends and Wedding Songs in Kangra. Ethos. Vol. 14, No. 1, pp. 47-75.

Raheja, Gloria Goodwin \& Gold, Ann Grodzins 1994. Listen to the Heron's Words: Reimagining Gender and Kinship in North India. Berkeley \& Los Angeles: University of California Press.

Saran, Parmatma 1985. The Asian Indian Experience in the United States. Cambridge: Schenkman Publishing Company.

Tedlock, Dennis 1991. The Speaker of Tales Has More Than One String to Play On. In: Ivan A. Brady (ed.) Anthropological Poetics. Savage, Md.: Rowman and Littlefield, pp. 309-340.

Tedlock, Dennis \& Mannheim, Bruce 1995. The Dialogic Emergence of Culture. Urbana: University of Illinois. 
Trawick, Margaret 1986. Internal Iconicity in Paraiyar "Crying Songs". In: S. Blackburn and A. K. Ramanujan (eds.) Another Harmony: New Essays on the Folklore of India. Berkeley: University of California Press, pp. 294-344.

Visweswaran, Kamala 1994. Fictions of Feminist Ethnography. Minneapolis: University of Minnesota Press. 